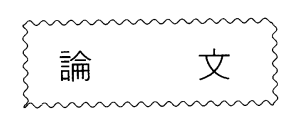

\title{
女子学生に拈ける食品摂取頻度と血清データとの関連
}

（第 1 報）緑黄色野菜摂取頻度と血清 $\beta$ 一カロテン濃度との関連

\author{
村上俊男 · 池田順子 \\ (京都文教短期大学)
}

\section{Relationship between Food-Intake Frequency and Analytical Data of Serum in Female College Students (Part 1) Relationship between Intake Frequency of Green-Yellow Vegetables and Serum $\beta$-Carotene Concentrations}

\begin{abstract}
Toshio Murakami and Junko Ikeda
Kyoto Bunkyo Junior College, 80 Senzoku Makishima-cho Uji-shi Kyoto, Japan

₹ 611-0041 京都府宇治市槙島町千足80

The relationship between food-intake frequency and serum $\beta$-carotene concentrations was investigated in 117 female college students. The findings are as follows. 1. The serum $\beta$-carotene concentrations were determined in the range of about 10 to $180 \mu \mathrm{g} / \mathrm{dl}$. The mean value was $64.4 \pm 30.7 \mu \mathrm{g} / \mathrm{dl}$. 2. A positive correlation $(\mathrm{p}<0.01)$ was observed between the intake frequency of green-yellow vegetables and the serum $\beta$-carotene concentration, when the food-intake frequency was divided into 5 categories, the frequency from twice or more a day to one or twice a month. 3 . The levels of serum $\beta$-carotene were markedly reduced in a lower category of the total intake freqencies of eggs, milks and diary products, retinol-rich foods. Among the retinol-poor category, the serum $\beta$-carotene levels proved low even in the group of high intake freqency of green-yellow vegetables. These findings demonstrate that the serum $\beta-$ carotene concentrations can be approximated by the intake frequency of green-yellow vegetables, and its level is reduced when the intake frequencies of some retinol-rich foods are very low e. g. less than one a week.
\end{abstract}

\section{1. 緒 言}

天然に存在するカロテノイドは約 600 種あり，その中 でも $\beta$ カカロンは, その摂取や血清濃度が高レベルで ガンの予防効果があるとの疫学調査が蓄積 1 ) 3)され, 注目の発端となった。しかし逆に， $\beta$ 一カテンの単独 大量投与ではむしろ肺ガン発生を増加させるとの報告 ${ }^{4)}$ も出て, 実際の効果やその人カニズムについては必ずし も一致した見解が得られていない.それに前後して, $\alpha-$ カロテン，フコキサンチン，ルテイン，リコピンなどの 発ガン抑制作用が明らかにされる ${ }^{5)}$ に及んで, カ口
テノイドのもつ抗酸化作用，すなわち活性酸素の障害防 止効果 ${ }^{6}$ 〜 8) がベースにあることがわかってきた.

このことはカロテノイドを含む食品の摂取が, 発ガン 抑制だけに留まらず, 疾病一般の予防や老化防止につな がることを意味している.カロテノイドの血中の濃度は, それら自身がヒトの体内では生合成されないので，摂取 した食品に由来する9) と考光られている。これまでに力 ロテノイドあるいは $\beta$-カロテン摂取量と血中カ口テ, イドとの動向を調査した報告は既にいくつかある10) 12) が，いずれも血中の $\beta$-カロテン濃度は $\beta$-カロテン摂取 量と正の相関があることを示している.この $\beta$-カ口テ 
ンを多く含む食品の代表として緑黄色野菜があげられ る. 緑黄色野菜の摂取量は, 詳細な食事秤量調査を行う ことにより把握できるが，池田ら ${ }^{13)}$ はとの摂取頻度から でもつかめることを報告している．

このことから, 習慣的に緑黄色野菜を摂取する頻度が 高い人ほど血中の $\beta$-カロテン濃度が高レベルに維持さ れているとの推察が成り立ち, 既報の一部にその記載14) も認められるが，詳細な報告はない、またプロビタミン Aでもあるß-カロテンは体内でビタミン A（レチノー ル）に変換されるので, レチノール摂取量が血中の $\beta$ カロテンレベルに影響を与えることも考慮する必要があ るが，両者の関係を実証した例15)も汪とんどなく，まし てや摂取頻度からのアプローチは見あたらない。

筆者らは, 疾病予防ひいては健康増進の立場から日常 の習慣的な食生活を把握する方法として, 実用上の手数 の煩雑さの少ない食品摂取頻度調査 (Food Frequency Questionaries: FFQ) 法の活用方法およびその有用性に ついて検討してきた (3),16), 17). 本研究では血清 $\beta$-カロテ ン濃度と $\mathrm{FFQ}$ との関連から， $\beta$-カロテンの血清レベル が緑黄色野菜の FFQ により把握できるのかについて検 討し，若干の知見を得たので報告する.

\section{2. 実験方法}

\section{(1) 対象者および時期}

対象は京都府内都市部に位置する短期大学の 1 回生の 女子118名で, 食生活習慣調査, 採血のいずれも，10月 中旬に実施した。

\section{（2）食生活習慣調查}

池田の考案した「食生活に関するアンケート」の一環 として食品摂取頻度調查を実施した。食品群は表 1 亿示 寸23項目から成り，その摄取頻度は，(1) 1 日 2 回以上、 (2)ほとんど毎日, (3)週に 3 5 回, (4)週に 1, 2 回, (5) 月に 1,2 回，66汪とんど食べない，の6 6 カテゴリーと した．ただし，(1)に該当する人数が少ない場合は，統計 処理上(1)と(2)を合わせて 1 カテゴリー（1 日 1 回以上）

\section{表 1 摂取頻度調查した食品群項目}

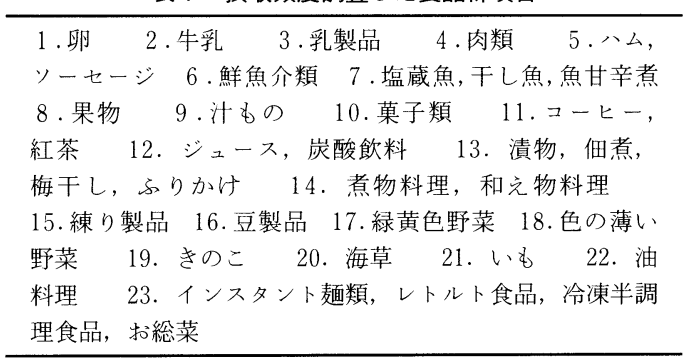

とした．また同時に，飲酒と喫煙の頻度についても調査 した。

\section{（3）採血および血清の調整}

採血は同意を得た上記の学生から，当日昼食を抜いた 状態で夕方行った．採血用試験管（血清採取用）に採血 し，直ちに遠心分離（3,000 rpm，10分）に上り，上清 として血清を得た。この血清は, 遮光下に $-35^{\circ} \mathrm{C} て ゙$ 涷結 保存し，カロテンの分析は 2 か月以内に行った。なお， この種の研究はヒトを対象とするものであるので，その 趣旨を日本食糧 ·栄養学会の倫理委員会に届け出, 承認 （No.2）を得て遂行している.

\section{(4) 血清 $\beta$-カロテンの分析}

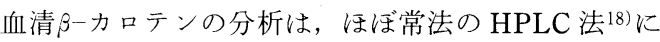
準拠したが, 抽出操作は一部に独自の改良を加えた方法 ${ }^{19}$ によった。すなおち，図1飞示すよらに，n一へキサン： ベンゼン $(5: 1, \mathrm{v} / \mathrm{v})$ の混液により抽出した試料液を

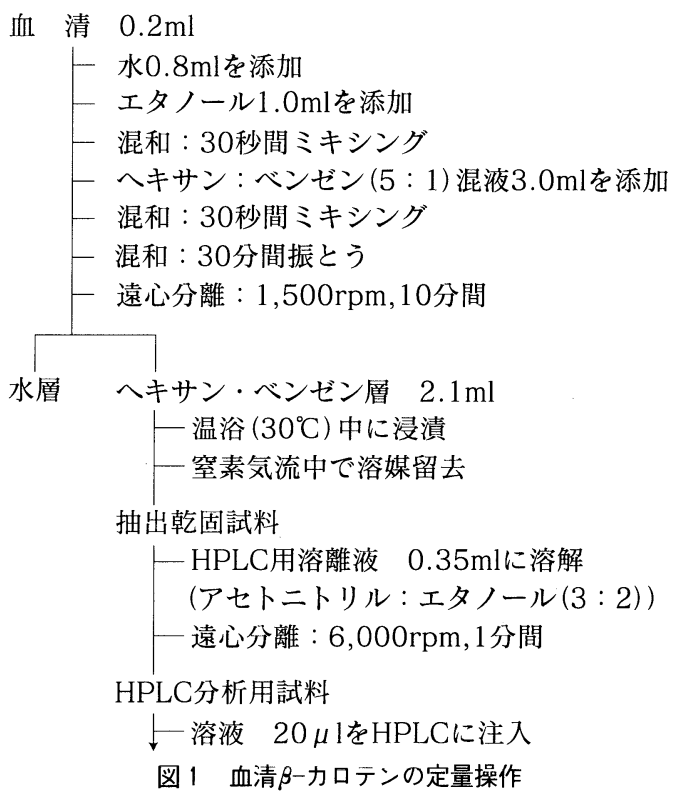

$\mathrm{N}_{2}$ ガスで蒸発乾固後, HPLCの移動相であるアセ卜= トリル：エタノール $(3: 2, \mathrm{v} / \mathrm{v})$ に溶解し, HPLC 分析に供した。装置は全て日立製で，ポンプはL-6000， 紫外 \& 可視部検出器は $\mathrm{L}-4200 \mathrm{H}$ ，カラムオーブンは $\mathrm{L}$ 7300を，それぞれ用いた。 カラムはナカライテスク社製 の Cosmosil 5C18-AR $(4.6 \phi \times 150 \mathrm{~mm})$ を使用した．上 述した移動相の流速は $1.0 \mathrm{ml} / \mathrm{min}$, カラム温度は $30^{\circ} \mathrm{C}$ で行い, カロテンの検出は $450 \mathrm{~nm}$ の可視吸収によった. 血清中の $\beta$-カロテンの同定は, 同条件にお打る標準物 質（メルク社製）との保持時間の一致により行った. 
$\beta$-カロテン濃度は当該標準溶液を用いる検量線に従っ て求めた.

\section{(5) 解析方法}

緑黄色野菜摂取頻度(1)（6)の各カテゴリー毎に，血清 ß一カ口テン濃度の平均值と標準偏差を求めた.レチノー ル含有食品（卵，牛乳および乳製品）の総合摂取頻度に ついては，個々の食品の摂取頻度（1)～(6)）をそれぞれ $1 \sim 6$ と対応する数字に置き換えて合計し $(3 \sim 18)$, それらを高頻度 ( $\leqq 9$ : 平均(3)), 中頻度 $(>9 \sim \leqq 12)$, 低頻度（>12：平均(4)）の 3 カテゴリーに分けて処理し た。それぞれのカテゴリ一間の差は，ひとまとめにして $\mathrm{F}$ 検定（一元配置分散分析）により，また 2 群間の差は $\mathrm{t}$ 検定により，それぞれ検討した。なお，上記の計算は 統計パッケージSPSSを用いた。

\section{3．実験結果および考察}

\section{（1）血清 $\beta$-カロテン濃度の分布}

定量に供した 118 人中血清 $\beta$-カロテン濃度の最大值は $172.3 \mu \mathrm{g} / \mathrm{dl}$ で，最小值は $17.3 \mu \mathrm{g} / \mathrm{dl}$ であった. このう ち, 毎日飲酒者は一人, 毎日契煙者が 3 人で, 飲酒・契 煙とも毎日と答えた一人の定量結果は, 最低值に近い $23.2 \mu \mathrm{g} / \mathrm{dl}$ であった. 飲酒・契煙の習慣化は血清 $\beta$-カ口 テンを変換あるいは消費させるとの報告 ${ }^{20)}$ があるので, このデータは本研究の解析対象からは削除した．その結 果, 117 人の血清 $\beta$-カ口テン濃度の平均値は 64.4 $\mu \mathrm{g} / \mathrm{dl}$, 標準偏羑は30.7といら結果になった。その全体 の分布状況は図 2 に示寸通りで, やや正に偏っていた. 女子学生の血清 $\beta$-カ口テン濃度の平均值としては, 既 報のもの14)とほぼ同レベルであった。

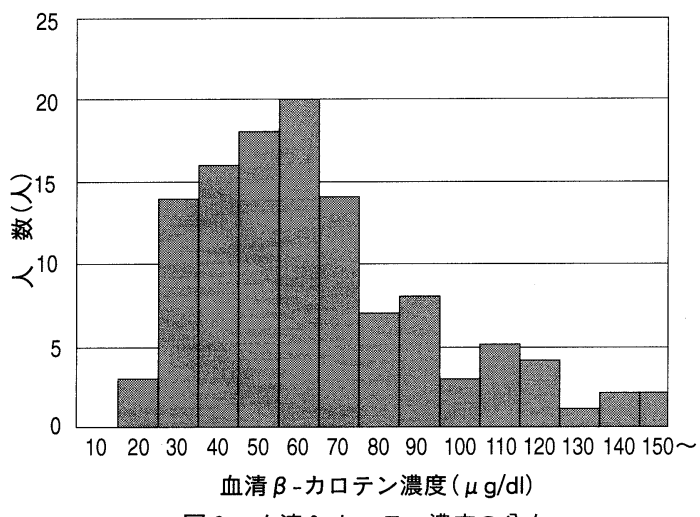

図 2 血清 $\beta$-カロテン濃度の分布

個々のデータの一桁目を四捨五入して 0 に丸め，145以上は 150 〜として処理した。

\section{（2）緑黄色野菜摂取頻度の現状と血清 $\beta$-カロテン濃度 との関連}

対象者 117 人の緑黄色野菜摂取頻度は，1 日 2 回以上

(1)）は 3 人，汇とんど毎日（2)）が 22 人，週に $3 \sim 5$ 回（3） が最多の55人, 週に 1, 2 回（4)）は31人で, 月に 1,2 回（5)）は 6 人，汇とんど食べない（6)人 はいないといら現状であった。

\section{表 2 緑黄色野菜摂取頻度と血清 $\beta$ 一カロテン濃度との関連}

\begin{tabular}{c|c|cc}
\hline $\begin{array}{c}\text { 緑黄色野菜 } \\
\text { 摂取頻度 }\end{array}$ & $\begin{array}{c}\text { 人 数 } \\
(\text { 人) }\end{array}$ & $\begin{array}{r}\text { 血清 } \beta \text {-カロテン濃度 } \\
(\mu \mathrm{g} / \mathrm{dl})\end{array}$ \\
\hline (1) 1 日 2 回以上 & 3 & $130.5 \pm 38.8$ & \\
(2) ほとんど毎日 & 22 & $71.7 \pm 30.5$ & \\
(3)週に $3 \sim 5$ 回 & 55 & $63.0 \pm 29.7$ & $\mathrm{p}<0.01^{*}$ \\
(4)週に 1, 2 回 & 31 & $58.4 \pm 25.7$ & \\
(5)月に 1, 2 回 & 6 & $46.0 \pm 10.0$ & \\
\hline
\end{tabular}

血清 $\beta$-カロテン濃度 : 平均值士標準偏差

* F 検定による 5 群間の差の有意水準

この 5 つのカテゴリーに属する対象者の血清 $\beta$-カ口 テン濃度の平均值と標準偏差を算出して, 5 カテゴリー 間の差を $\mathrm{F}$ 検定した結果を表 2 に示す。緑黄色野菜摂取 頻度(1)〜(5)のカテゴリ一毎の血清 $\beta$ 一カロテン濃度の平 均值をみると, (1)が $130 \mu \mathrm{g} / \mathrm{dl}$ と非常に高く, (2)は72 $\mu \mathrm{g} / \mathrm{dl}$ となり, 以下摂取頻度が下がるに従いその濃度は $5 \sim 9 \mu \mathrm{g} / \mathrm{dl}$ ずつ減少し，この 5 カテゴリー間の差は有

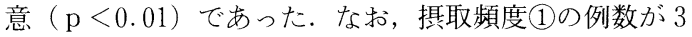
人と少ないので，(1)+(2)を 1 カテゴリー $(\mathrm{n}=25)$ と見

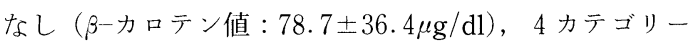
で再検定したが，やはり 4 カテゴリ一間の差は有意（p く0.05）であった. すなわち，緑黄色野菜摂取頻度が習 慣的に高ければ血清中の $\beta$-カロテン濃度は高く, その 摂取頻度が低くなるに従って血清 $\beta$ 一カロテン濃度が低 レベルになる傾向にあることが明らかになった。なお，

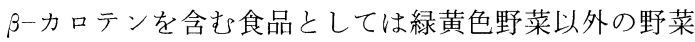
や海草もあるが, これらの食品の摂取頻度を考慮しても， 緑黄色野菜摂取頻度と血清 $\beta$-カ口テン濃度との関連は 変わらなかった。

（3）レチノール含有食品摂取頻度と血清 $\beta$-カロテン濃 度との関連

ビタミン A (レチノール) の栄養所要量は女子学生で $1,800 \mathrm{IU}$ であり, レチノールと $\beta$-カロテンとから等分 に摂取することが望ましい。しかし，レチノールの摄取 量が多ければ，プロビタミンAである $\beta$ ーカロテンは, ビタミンAに変換されずにそのまま残るといわれてい る.そこで，特にレチノール高含量で摂取量も多い食品 
として卵，牛乳および乳製品を取り上げ，その摂取頻度 が血清队ーカロテン濃度に及涪す影響を, 直接あるいは 緑黄色野菜摂取頻度を通して検討した。

まず，上記 3 つ個々の食品群の摂取頻度之血清 $\beta$ カロテン濃度との間には, 関連は認められなかった。例 光ば, 卵の摂取頻度を一日 1 回以上 (1) + (2) )とそれ未 満（3)+(4)+(5)+(6)）に分けて算出した血清 $\beta$-カロテ ン濃度は, 前者 (45人) が $64.9 \pm 30.7 \mu \mathrm{g} / \mathrm{dl}$ で後者（72 人）は64.1 $\pm 30.7 \mu \mathrm{g} / \mathrm{dl}$ と全く差はなかった。他の 2 食 品についても同様の傾向であった。

しかし， 3 食品群の総合的な摂取頻度（1） (6) × 3 食 品）と血清 $\beta$-カロテン濃度との関係をみると, 低摂取 頻度群で血清队一カロテン濃度が低い傾向にあった。そ こで，このレチノール含有食品の搷取頻度を高（平均で 週 $3 \sim 5$ 回以上) . 中. 低 (平均で週 1 回未満) のカテ ゴリーに分けて，この 3 カテゴリー間の血清 $\beta$-カロテ ン濃度の差を $\mathrm{F}$ 検定したところ（表 3 ), 高摂取頻度群 では $65.3 \mu \mathrm{g} / \mathrm{dl}$, 中摂取頻度群では $68.3 \mu \mathrm{g} / \mathrm{d} 1$ と差がな いのに対して, 低摂取頻度群では $46.8 \mu \mathrm{g} / \mathrm{dl}$ と低い傾向 $(\mathrm{p}<0.06)$ がみられた。すなわち，レチノール含有食 品群の平均拱取頻度が週 1 回にも満たない 15 人（全対象 者の約 $13 \%$ 亿相当）の血清 $\beta$-カロテンレベルが低かっ たことを示している.

次に，レチノール摂取頻度に応じた 3 つカテゴリー

表 3 レチノール含有食品および緑黄色野菜の摂取頻度と血清 $\beta$-カロテン濃度との関連

\begin{tabular}{|c|c|c|c|}
\hline $\begin{array}{l}\text { レチノール含有食品 } \\
\text { 摂取頻度/血清 } \beta \text { - } \\
\text { カロテン浱度 } \\
(\mu \mathrm{g} / \mathrm{dl}) *\end{array}$ & $\begin{array}{l}\text { 緑黄色野菜 } \\
\text { 摂取頻度 }\end{array}$ & 血清 $\beta$ - & $\begin{array}{r}\text { テン濃度 } \\
(\mu \mathrm{g} / \mathrm{dl})\end{array}$ \\
\hline \multirow[t]{2}{*}{$\begin{array}{l}\text { 高 }(\mathrm{n}=49) \\
\quad / 65.3 \pm 31.7\end{array}$} & 高 $(\mathrm{n}=16)$ & $\begin{array}{l}84.1 \pm \\
35.0\end{array}$ & \multirow{2}{*}{$\begin{array}{r}* * \\
\mathrm{p}<0.01\end{array}$} \\
\hline & 低 $(\mathrm{n}=33)$ & $\begin{array}{l}56.4 \pm \\
26.0\end{array}$ & \\
\hline \multirow[t]{2}{*}{$\begin{array}{l}\text { 中 }(\mathrm{n}=53) \\
\quad / 68.3 \pm 31.6\end{array}$} & 高 $(\mathrm{n}=5)$ & $\begin{array}{l}90.7 \pm \\
38.9\end{array}$ & \multirow{2}{*}{$\begin{array}{l}{ }^{* *} \\
\mathrm{NS}\end{array}$} \\
\hline & 低 $(\mathrm{n}=48)$ & $\begin{array}{l}66.0 \pm \\
30.3 \\
\end{array}$ & \\
\hline \multirow[t]{2}{*}{$\begin{array}{l}\text { 低 }(\mathrm{n}=15) \\
\quad / 46.8 \pm 13.9\end{array}$} & 高 $(\mathrm{n}=4)$ & $\begin{array}{l}42.2 \pm \\
16.7\end{array}$ & \multirow{2}{*}{$\begin{array}{l}* * \\
\mathrm{NS}\end{array}$} \\
\hline & 低 $(\mathrm{n}=11)$ & $\begin{array}{l}48.5 \pm \\
13.3\end{array}$ & \\
\hline
\end{tabular}

血清 $\beta$-カロテン濃度 : 平均值土標準偏差

$* \mathrm{~F}$ 検定による 3 カテゴリー（高，中，低）間の差の 有意水準 $: \mathrm{p}<0.06$

** $\mathrm{t}$ 検定による 2 群（高, 低）間の差の有意水準
それぞれについて，緑黄色野菜摄取頻度が一日 1 回以上

（高： (2)）とそれ未満（低：>（2)）とに分けて，それ ぞれの 2 群間の血清 $\beta$ 一カロテン濃度の差を $\mathrm{t}$ 検定によ り比較した（表 3 )。そ結果, レチノール含有食品の 高叔よび中摂取頻度群では緑黄色野菜の摂取頻度が高い 程血清队一カロテン濃度も高いといら傾向がみられた（た だし，統計上有意であったのは高摂取頻度群のみであっ た）が，レチノール低摂取頻度カテゴリーでは緑黄色野 菜摂取頻度に関わりなくほぼ同レベルであり，その值は 本対象者全体の平均值を $25 \%$ も下回っていた。レチノー 儿摂取が十分であれば $\beta$-カロテンはそのまま残るので， その血清值は緑黄色野菜摂取頻度飞依存寸るが，レチ ノールの摂取不足は $\beta$-カ口テンのレチノールへの変換 を促すので， $\beta$--カロテンの血清レベルは低くなると解 积されていることが，FFQにより本対象者で実証でき た.

これらの結果は, 血清 $\beta$-カロテン濃度は緑黄色野菜 摂取頻度に依存するが，レチノール含有食品群の摂取頻 度が極端に低い場合は， $\beta$-カロテンの血清レベルがさ らに下がると見なす必要があることを意味している。す なわち, 食品の摂取頻度から血清の $\beta$-カロテンレベル を推定する場合, 緑黄色野菜に加えてレチノール含有食 品群（卵，牛乳および乳製品）の摂取頻度も考慮に入れ る必要性を示唆して抢り, 健康上からい光ば, カロテン だけでなくレチノールの撕取も重視しなければならない ことがわかった。

健康のバロメーターの一つとしての血清队-カロテン レベルが，煩雑な秤量調查をしなくても簡易な $\mathrm{FFQ}(し$ か子緑黄色野菜と特定のレチノール含有食品のみ）によ り，大まかに把握できることが明らかになったことは， 今後健康教育・相談を展開する上で有意義な成果である と考劣る、ただ，今回は対象者数が 100 余名と少なかっ たためか, 緑黄色野菜掑取頻度間の血清 $\beta$-カロテン濃 度の差を明確に実証することができなかったので，今後 例数を増やし，両者の関係についてさらに検討したいと 考光ている.

\section{4. 要約}

女子学生 117 人を対象にした食品摂取頻度調查 $(\mathrm{FFQ})$ と, 同時期飞行った採血からの血清 $\beta$-カロテン分析值 を元に，統計処理により両者の関連を検討したところ， 以下のような結果が明らかになった.

(1)血清 $\beta$-カロテン濃度は, $10 \sim 180 \mu \mathrm{g} / \mathrm{dl}$ の範囲に納 まり，やや正に偏った分布を示した，その平均值と標準 


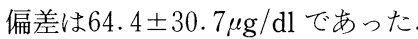

(2)緑黄色野菜拱取頻度 1 日 2 回以上から月に 1,2 回 までの 5 カテゴリーに拈いて，血清 $\beta$-カロテン濃度の 平均值を算出したところ，1 日 2 回以上では $130.5 \mu \mathrm{g} / \mathrm{dl}$ と最も高く, 摂取頻度が低下する程そのレベルも低下し, 5 カテゴリ一間の差は有意 $(\mathrm{p}<0.01)$ であった.

(3)レチノール含有食品として卵，牛乳拉よび乳製品を 取り上げ，これら 3 食品群を総合した摂取頻度を高・中 ・低の 3 カテゴリーに分けて, 血清 $\beta$-カロテン濃度と の関連をみたところ, 平均の摂取頻度が週 1 回にも満た ない低摂取頻度群の血清 $\beta$-カロテンレベルは著しく低 くかった $(46.8 \mu \mathrm{g} / \mathrm{dl})$. また，このレチノールの摂取不 足は緑黄色野菜の摂取頻度が高くても, 血清 $\beta$-カ口テ ンレベルは明らかに低い傾向であった。

以上のことより，食習慣の指標である緑黄色野菜摂取 頻度がわかれば，血清中の $\beta$-カロテン濃度が把握でき るといらこと, またレチノール含有食品群の掑取頻度が 極端に低い場合には, 血清 $\beta$ 一カロテンレベルがより下 がると見なす必要があることが明らかになった。

\section{文献}

1) Peto, R., Doll, R., Buckley, J. D. and Sporn, M. B. :Nature, 290, 201 (1981)
2) Staehelin, B. H., Gey, G. F., Eicholzer, M. and Luedin, E. :Am. J. Clin. Nutr., 53, 265S (1991)

3) Blot, W. J., Li, J. - Y., Taylor, P. R., Li, B. et al. :J. Natl. Cancer Inst., 85, 1483 (1993)

4) The Alpha-Tocopherol, Beta-Carotene Cancer Prevention study Group :N. Enql. J. Med., 330, 1029 (1994)

5）西野輔翼, 岩島昭夫：ビタミン, 67, 531 (1993)

6) 末木一夫 : 油化学, 40, 893 (1991)

7) Di Mascio, P., Kaiser, S. and Sies, H. : Arch. Biochem. Biophys., 274, 532 (1989)

8) Krinsky, N. I. : Free Radical Biol. Med., 7,617 (1989)

9）松野隆男, 幹 渉: 化学と生物, 28, 219 (1990)

10）木下伊規子, 木村典代, 加藤達雄 : 日本栄湌 ·食糧学 会誌, 48, 29 (1995)

11）大嶋俊二, 小嶋文博, 石黒幸雄ら：日本栄養 -食糧学 会誌，48，365（1995）

12）伊藤宜則，清水弘之，鈴木康司ら：ビタミン，71，427 (1997)

13）池田順子，永田久紀，宾岡市光5：日本公衆衛生雑誌, 42, 829 (1995)

14）赤澤典子：日本家政学会誌，47，1023（1996）

15）坂本秀樹, 大嶋俊二, 福場博保 5 : 日本栄屓. 食糧学 会誌，50，21（1997）

16）池田順子, 永田久紀ら：日本衛生学雑誌, 43, 907 (1988)

17）池田順子, 永田久紀ら：日本衛生学雑誌, 44, 847 (1989)

18）加美山茂利, 田近久美子, 伊藤宜則：臨床検查, 31 , 286 (1987)

19）村上俊男：京都文教短期大学研究紀要，35，156（1996）

20) Aoki, K., Ito, Y., Sasaki, R., Asano, A. et al. : Jpn. J.Cancer Res. (Gann), 78, 1049 (1987) 